American Journal of Economics and Business Administration 4 (1): 105-115, 2012

ISSN 1945-5488

(C) 2012 Science Publications

\title{
The Growth of Small Businesses: Towards A Research Agenda
}

\author{
Akin Fadahunsi \\ Department of Business Administration, School of Arts and Sciences, \\ Baptist Bible College, 538 Venard Road, Clarks Summit, PA18411, USA
}

\begin{abstract}
Problem statement: The central objective of this study is to help define a framework for researching the growth of small businesses. Approach: By way of a literature review, the study evaluates current research approaches to small business growth organized around the "key factors" framework proposed which include elements drawn from the characteristics of the entrepreneur, the firm and the business strategy. Results: In the absence of a unified theory of small business growth, models and approaches used to explain small business growth are fragmented and wide-ranging. A consideration of the additional impact on this framework of the external environmental dimension can inject a necessary dynamic element into the research process that is well-placed to capture the process of firm growth, as opposed to the snapshot of firm growth that tends to dominate the existing empirical work. Conclusion: The study concludes that longitudinal and case-based methodologies are needed to develop our existing understanding of small firm growth behavior.
\end{abstract}

Key words: Entrepreneurship, business growth, small business research, small business development

\section{INTRODUCTION}

The central objective of this study is to help define a framework for researching the growth of small businesses. Its intended contribution is to the literature on analytical frameworks for small business development. The study does this by reviewing the central tenets of Storey's (1994) key factors approach to analyzing small business growth in the light of its use in a variety of empirical studies. Storey proposed a threepronged analysis that includes elements drawn from the business owner, the business itself and the strategies pursued by the business. In this analysis I intend to additionally review the impact of environmental factors which I argue is well-placed to capture the inherently uncertain external conditions that most small businesses tend to operate under.

The small business sector is especially worthy of note since the bulk of enterprise entries and exits in the American (and indeed global) economy occur within it (Headd, 2010), and energizing this sector has emerged as a key policy challenge in the aftermath of the economic downturn of the early 2000s. The contributions of SMEs into economic development are well documented, particularly in terms of their role as employment generators and sustainers and as the reservoir of innovation from which not only the enterprise owners benefit but from which the wider economy also benefits (Audretsch, 2002; Craig and Kohlhase, 2006; Kobe, 2007). However, if these contributions are to be maximized, it will be necessary from a policy standpoint to not only take steps that will ensure the continued formation of small businesses, but also to take steps that are intended to ensure the survival and prosperity of the businesses that do get started. A policy framework that does not look beyond enterprise creation and further into their sustainability would seem to be incomplete in its reach. Equally, a policy framework that is not embraced by the firms that are its intended beneficiaries would have failed a key delivery outcome. These provide the policy context for this study.

On the conceptual front, an initial concern pertains to the analytical use of "small business". In the United States, a Small and Medium Enterprise (SME) is officially defined as one employing less than 500 persons (USSBA, 2004) (An employment threshold of 100 and 20 mark businesses out as "small" and "micro" businesses, respectively). This categorization covers approximately $99 \%$ of all US firms, which may suit a variety of purposes, but also lays the ground for other concerns. Analysis of US Census Bureau's Statistics of US Businesses (SUSB) shows that $95 \%$ of new employer firms actually have less than 20 employees (Headd, 2010) and that the median US employer's firm size is in fact just four employees (Headd and Kirchhoff, 2009), so while there may be certain advantages to setting the employment threshold for SMEs at the 500 mark, it is also quite apparent that it carries the possibility of accommodating a variety of 
enterprises that significantly differ in their constitution and operations, which could limit the analytic usefulness of this categorization. "SMEs" are a highly diverse group of firms that differ not only in terms of employment levels, but also in terms of revenue, ownership, culture, managerial style and so forth (Headd and Saade, 2008). It would be difficult to categorise them into neat sub-groups, let alone to construe of them as one homogeneous group. Nonetheless, there remain some broadly observable features associated with smaller firms that appear to collectively distinguish them from other enterprise forms. One of the more visible ones is that smaller businesses tend to have relatively simple and flexible structures that help to simplify their management processes. Typically, only a few people (and sometimes just the business owner) are involved in the decisionmaking process. They also tend to possess relatively limited managerial resources (Carter and Jones-Evans, 2000) which can cause their owner-managers to be simultaneously involved in several organizational functions, with the result that the scope of duties can become so wide that the business owner/manager may be insufficiently skilled or knowledgeable to carry out the full range of required managerial tasks.

However we define it, the importance of the SME sector as a driver of economic development cannot be overstated. In its 2008 report on the state of small business affairs in America, the United States Small Business Administration (SBA) reported that small businesses employ about half of the American workforce and provide approximately half of the nation's non-farm, private GDP. It went on to note that even in the deteriorating economic climate that the country began to experience in 2007, 74\% of the 1.1 million new net jobs in the economy were created in SMEs and specifically that $22 \%$ of these new net new jobs were created by businesses employing less than 20 people (USSBA, 2008). Since about three quarters of America's small businesses do not in fact have any employees besides the owner (Headd and Saade, 2008), this offers indicative support to the small business literature (Storey, 1994) which suggest that a "tiny" proportion of high performing small firms tend to be responsible for about half of all employment generated by small firms as a whole. It therefore stands to reason that firms that are small and growing are likely to be significant job creators, which provides a further policy dimension for research interest in the activities of such firms.

The rest of the study proceeds with a review of aspects of the literature relating to small business survival and growth. Emphasis is placed in this review on empirical studies, on the basis of which a series of propositions about the dynamics of small firm growth are examined. The study concludes with some remarks about some implications for future empirical research work.

\section{Conceptualizing small business growth:}

Growth and/or Survival? Intuition suggests that some of the same factors that influence the survival of small firms can similarly influence their growth and in that sense might foster the argument that a firm's survival and growth are positively associated. However, distinguishing between firm survival and growth is beneficial for two analytical reasons: First, as qualitative indicators go, business 'survival' and 'growth' are distinct aspects of organizational performance that are determined by different purposes. As noted by several commentators (e.g., Kalleberg and Leicht, 1991; Smallbone et al., 1995), the growth objective is not one that is universally sought by small business owners. Individuals start businesses for a variety of reasons including lifestyle-based ones which may cause the business owner to operate the business with little or no growth orientation. It is also possible that a founder's business intentions change. Someone may start a business that they intend to expand and due to a change of heart or other circumstances, later abandon that intention. In these instances, the absence of a growth intention in the founder could directly translate to the organization.

Secondly, there is some evidence to support the notion that there are qualitative differences between the strategic approach of firms that are intentionally seeking to grow and those that are merely seeking to survive. This was demonstrated in a study by Smallbone et al. (1995) and Ram et al. (1997) in which the authors investigated a panel of about 300 firms in England over a ten-year period in the 1980s and found that firms which had experienced "high growth" during the study period had made a number of adjustments to their business strategy that were in sharp contrast to those made by firms that had merely survived the same period, suggesting that even though both survivaloriented and growth-oriented firms may co-exist under similar environmental conditions, one can expect differences in their strategic responses to the elements present in their environment.

Approaches for analyzing small business growth: Although a large body of literature exists on small business growth, it remains the case that no single, overarching model of small firm growth exists (Dobbs and Hamilton, 2007). The factors that affect small business growth and the ways in which those factors 
interact are quite varied in nature, thus cohesive and comprehensive empirical studies on the subject are difficult to conduct and the resulting literature remains rather fragmented. It is usually possible to draw inferences that explain certain context-specific aspects of small firm growth, but in the final analysis, an objective, comprehensive and predictive model of small firm growth appears to be beyond the reach of small business commentators with the result that they quite commonly make academically or logistically pragmatic choices about the use and interpretation of data on small firm growth. One aspect in which this is evident is the important issue of measuring "growth" in small firms.

The case has been made for increases in revenue (Smallbone et al., 1995) and employment (Storey, 1994) as key small firm growth indicators in part because they are visible and relatively easily obtainable units of measurement. It is arguable that other methodsincreases in profits or capital assets, for examplepotentially offer more objective measurements of firm growth (Carter and Jones-Evans, 2000). However, as many researchers are aware, reflecting this in research design tends to be problematic. First, the factors that influence one growth measure (e.g., increase in profits) may not necessarily influence another (e.g., increase in employment) and secondly, a critical hurdle that negatively impacts the use of certain capital assets like profitability to measure small firm growth concerns the difficulty of accessing relevant data, given the reticence of respondents to share the finer details of their firms' financial performance. These make it difficult to make a conceptual case for the absolute advantages of one growth measure over other, but it is less challenging to draw a logistical distinction. So, while an increase in asset value, market share and profit may all generate objective data with which to measure small business growth, because of their relative ease of access, the more pragmatic units of analysis for most research purposes will be employment or revenue change. For all the intricacies of what may or may not constitute growth in a form that is acceptable to the population of academic researchers, policy planners also appear to be most focused on these two measurements: employment growth, which addresses jobs concerns and sales growth, which addresses taxation concerns.

Factors influencing small business growth: We now turn to a summary examination of a number of influential factors on firm growth. They are listed in Table 1 below and draw upon Storey's (1994) seminal "key factors" framework for analyzing small business growth in which he identified the interplay of three categories of influences on firm growth: those that relate to the entrepreneur, those that relate to the firm and those that relate to the selected strategy. They are discussed in turn below. To these three categories is added the external environment which provides the operating context for entrepreneurial behavior which individual small firms can respond to, but do little to change (Birley and Muzyka, 2000; Burns, 2001). It is discussed as a fourth category (Table 1). It is however worth noting before this discussion that the intent is not to attach any particular weight at this point to the relative importance of these factors but to rather acknowledge their potential to be contributory factors to firm growth on the basis that they have been so identified in the small business literature.

Entrepreneurs' characteristics: These refer to the characteristics of the person or persons that provide the key resources used in establishing the business. They are typically identifiable prior to establishing the business and include a range of personal and behavioral characteristics (see further Davidsson, 1989). Whist the analyses of these factors have enjoyed success with explaining entrepreneurial behavior (Morris et al., 2006), methodologically, their ability to predict successful from unsuccessful entrepreneurial behavior is rather more suspect (Storey, 1994). Nevertheless, an individual may possess entrepreneurial abilities that are distinctive from the corporate entrepreneurship of their business organization (Iacobucci and Rosa, 2005). Factoring in the coalescence of ownership and management in smaller businesses (Carter and Jones-Evans, 2000), it can be hypothesized that several personal characteristics of business owners are potentially contributory to the growth prospects of their businesses. A summary examination of these factors follows.

Motivation: As noted earlier, growth is not universally desired or sought by small business owners and even though growth motivation is not considered to be the single determining factor in explaining whether or not a firm in fact achieves growth, it can be expected to significantly influence the strategic choices made by those that seek it. Smallbone et al. (1995) for instance showed that the high growth respondents in their panel were more than twice as likely to have a growth objective as other firms in their panel. It can be hypothesized, then, that a business that is begun with 'positive' motives (e.g., spotting a market gap) is more likely to grow than one begun with 'negative' motives (e.g., disaffection with the owner's previous employment). 
Am. J. of Economics and Business Administration 4 (1): 105-115, 2012

Table 1: Factors influencing firm growth

\begin{tabular}{llll}
\hline Entrepreneurial & Organization & Strategic & Environmental \\
\hline Motivation & Age & Workforce training & National/regional \\
Education & Sector & Management training & Sectoral \\
Ownership/management experience & Location & Marketing strategy & Local \\
Number of founders & Size & Internationalization & \\
Ethnicity/race & Ownership FORM & Technical resources & \\
Age & & Planning & \\
Gender & & External advice and support & \\
& & Financial resources & \\
\hline
\end{tabular}

Education: As an enterprise management tool, the level of education possessed by the business owner may not necessarily be an end in itself, but it can enhance the entrepreneur's motivation and ability to use a number of skills that are useful in managing enterprises (Storey, 1994). It can also provide certain disciplinespecific advantages for entrepreneurs who choose to go into business in areas in which they have been formally educated (e.g., bio-technology or graphic design) and it may further help to set the owner's expectations of their venture earnings in a scenario that is best met in the context of a growing business (Dobbs and Hamilton, 2007). In this sense, it may be expected that more "educated" business owners have a greater likelihood of forming faster-growing businesses than their less educated counterparts.

Ownership/management experience: Researchers have sought to connect the business owner's previous management experience-typically in a previous business ownership or employment-to the growth orientation of the firm. One line of hypotheses is that for a variety of reasons, business owners who previously owned other businesses may be inherently more cautious than those unburdened by such experience and may therefore not have a growth objective (Storey, 1994). A converse hypothesis has also been put forward, especially with regard to incidences of portfolio entrepreneurship, in which such ownership/management experience is considered to be a resource in itself to the extent that it that can steer the firm towards growth-related opportunities whilst helping it to avoid growth-related pitfalls (Iacobucci and Rosa, 2005). As such, business owners with prior management experience are thought to be likelier to form faster-growing businesses than those established by individuals without that experience.

Number of founders: Attempts have been made to connect the diversity of experience and resources with which the business is started to the growth orientation of the firm. Although findings exist which indicate that the growth orientation in small businesses that are established with multiple founders may be inhibited by conflict amongst the founders (Dobbs and Hamilton, 2007), empirical studies (e.g. Morris et al., 2006) tend to support the notion that businesses established by multiple owners are likelier to grow faster than those established by individuals acting alone.

Ethnicity/Race: US Census data analysis shows that there is a higher proportion of self-employment in the immigrant population than there is in the indigenous population (Fairlie, 2008; Lowrey, 2010), a growing trend that has been reported to be a measure to counteract the effects of societal marginalization. Several studies have attempted to research aspects of minority ethnic entrepreneurship and specifically to seek the connection, if any, between entrepreneurial behavior or performance and entrepreneurs' sociocultural background. In this framework, aspects of the business owner's socio-cultural attributes (in particular ethnicity or race) are connected to the growth orientation of the firm, the implication being that these attributes are themselves resources that form a basis of the firm's competitiveness (Fadahunsi et al., 2000; Bagwell, 2008; Assudani, 2009; Scott et al., 2012). Even if this were the case, the ability to tap into available co-ethnic resources does not necessarily translate to higher business acumen for those founders nor does it necessarily indicate that they have better access to business support services than other segments of the population. By itself therefore, the race or ethnicity of the business owner is thought to be unlikely to have a significant impact on the growth orientation of a business.

Age: The idea is to connect the age of the business owner at the time the business is started to the firm's subsequent growth orientation. Generally, middle-aged business individuals have been reported (e.g., in Storey, 1994; Carter and Jones-Evans, 2000) as being more likely to possess the best mix of experience, credibility, energy and resources (and so more likely to own a growing business) than other business owners that are by contrast younger (having more 
energy but less experience, credibility and resources) or older (having more experience, credibility and resources but less energy).

Gender: Several studies have examined the impact of gender on the management of small businesses and while certain factors have been identified as influential management issues that have a distinctive gender dimension (e.g., access to support, finance, premises and childcare were thus identified by (Fielden et al., 2003), most empirical studies that have examined this subject (e.g. Morris et al., 2006; Robinson and Finley, 2007) have tended to conclude that by itself, the business owner's gender is not a significant factor in explaining a small firm's growth behavior.

Firm characteristics: These refer to key decisions made upon commencing the business which have an important bearing on the way the business is managed. They are identifiable at the start-up phase (i.e., when the business begins to trade) and as such, they are distinguishable from the business owner's pre-start-up access to resources, or to routine operational decisions made in the normal course of running an enterprise. Perhaps the most common use of this model examines the relationship between firm growth and the organization of the business as it transforms from a newer enterprise into a more established one. In this framework, growth is conceptualized as occurring in distinctive stages as a firm successfully overcomes certain situational challenges, the process of which necessitates changes in five management factors, namely the firm's organizational structure, managerial style, use of formal systems, strategic goals and the level of involvement of the owner (see further Birley and Muzyka, 2000). Much is made in the model of recognizing the growth of a business as occurring in a 'life cycle' context, with each stage of the cycle exhibiting distinctive characteristics in each of the five categories listed above. Entrepreneurial narratives tend to support the idea of 'critical thresholds' in the life of a business (Carter and Jones-Evans, 2000), but questions are nonetheless raised about the formalization of these processes in the stages-of-growth model (Dobbs and Hamilton, 2007) due to the assumptions it appears to make about business owners' intentions or abilities to grow and its further assumptions of a more or less linear business growth pattern or of growth being typically triggered by a point of crises. Nonetheless, the stage-ofgrowth model is valuable as a descriptor of the types of adjustments that a small business may need to make with regard to specific functional areas (e.g., in marketing or human resources) as it grows, if rather less so as a predictor of those adjustments. A summary review of the key factors examined under this approach follows:

Age: Typically, younger small firms are shown to grow more rapidly than older ones because they need to grow in order to be better able to guard against unforeseen environmental stresses (Kangasharju, 2000), but caution has been raised with respect to this proposition. Carter and Jones-Evans (2000) note with respect to other research that observed discontinuities in small firm growth shows that a firm's age is not a reliable predictor of its growth propensity. Reliance on firm age was also questioned in a population analysis of US small firms over a ten-year period in which it was demonstrated that the proportion of new small firms that experienced increases in employment levels during the study period were broadly similar to the proportion of established firms that did not and additionally that there was not a statistically significant difference between the population of new firms and established firms that experienced no changes in their employment levels during the same study period (Headd and Kirchhoff, 2009). These provide firm grounds on which to propose that younger firms are not significantly more likely to grow than more established ones.

Sector: The sector in which a firm operates is considered an influential factor on the growth processes in small firms but the extent to which it is a significant factor is less clear-cut. Although the level of industrial disaggregation can be expected to influence the results of sector analysis, empirical studies (e.g., Smallbone et al., 1995) usually find that there are significant differences amongst sectors in terms of the typical firm growth rates.

Location: The idea is to connect the location of the business to its growth orientation. Generally speaking, location tends to be conceived of in an urban-rural split and both types of locations have been identified as potential sources of both benefits and constraints (Ram et al., 1997; Fielden et al, 2003; Robinson and Finlay, 2007). Since this will have to be a matter operationalized on a study-by-study basis, for our present purposes, the likely impact of the location of a particular panel of respondents on their growth behavior will have to remain an open question.

Size: Here, "size" pertains to the employment levels in the firm. Generally, smaller firms tend to be reported as growing more rapidly than larger firms, with the exception of non-employer sole proprietorships, many of which are not established with a view to providing employment for anyone apart from the owner. 
However, according to the United States SBA, in recent years, the most job creation has been in small high growth firms with 20 or more employees (USSBA, 2008) although this employment pattern has been rather divergent (Headd and Kirchhoff, 2009). A cautionary note must therefore be sounded on this issue as the specific findings can be expected to be influenced by the employment levels at the commencement and conclusion of the study period.

Ownership: The reference here is to the firm's legal status and in that sense, the idea is to connect the form of ownership of the business to its growth propensity. It is usually reported that limited liability companies grow more rapidly than sole proprietorships or partnerships (Storey, 1994) although this finding may be one that is affected by the research design. In empirical studies, measurements of firms' legal status typically report on current, rather than start-up status, but it is of course quite possible that incorporation occurs as a result of growth, rather than as a cause, so it would be beneficial for empirical studies to take both measurements (i.e., current and start-up ownership forms) in part to address this issue.

Business management practices/strategies: These refer to managerial actions made on behalf of the enterprise, after the business has commenced trading. The ability of a business to plan its development around a realistic analysis of its resources is typically held in the management literature to be indicative of the firms's ability to survive and grow (Kraus et al., 2006). Whilst this approach undoubtedly has merit, it may also underplay the effects of some of the distinguishing features between the management of larger and smaller businesses, in effect interpreting size characteristics as growth characteristics. A summary review of the key factors that fall in this category follows.

Workforce training: This remains a highly topical issue in small business research. Generally speaking, the idea is to connect the level of training afforded a firm's employees to the firm's propensity to grow. Savery and Luks (2004) found in a longitudinal study that firms with an expressed growth intention were also more likely to be involved in training. They also found the converse to be true: Firms that had decided to reduce their production levels also tended to reduce their training. This lends credence to the typically positive association that is made between the existence of employee training and small firm growth (Storey, 1994). Conceptually however, debates surround the appropriate constitution of "training" in small firms, with questions concerning the formality, providers and locations of training (Storey, 2004). Moreover, as the likelihood of employee training seems to be more definitively associated with a firm's greater size - as opposed to growth per se-(Savery and Luks, 2004), it remains an open question whether a growing small firm is more likely to engage in workforce training than one that is not.

Management training: Related to the emphasis on workforce training is that on management training. Essentially, a firm can be expected to require the services of individuals in supervisory/managerial roles once employee numbers expand to certain levels. Such competencies may be developed in-house, or "bought" in via the firm's recruitment practices but as with workforce training, empirical studies have positively, but not conclusively associated management training with the subsequent growth of small businesses (see for example Chaganti et al., 2002; Storey, 2004; Alarape, 2007) and so the impact of management training on the firm's subsequent growth must, in effect, also remain an open question.

Marketing strategy: Marketing strategy is broadly understood to provide an articulation of a firm's best use of its resources and the tactics to achieve its marketing goal in a given market (Perrault et al., 2010). In the case of most small firms, this is unlikely to be a price-led effort since they are typically unable to achieve the required scale economies. Rather, marketing strategy development in small firms tends to center on varying degrees of differentiation, often involving new product development and/or positioning the firm to operate in profitable niches. For instance, in Ram et al. (1997), the authors found that over a tenyear period, the high -growth firms in their sample were one and a half times as likely to make significant changes to their marketing strategies (aimed at developing new products and/or markets) as firms that merely survived and about twice as likely as firms that experienced employment decline during the same period. However, a cautionary note must be sounded here: In the area of new product development for instance, a common proposition is that rapidly growing firms are more likely to have made more new product introductions than slower growing firms (Storey, 1994), but in making such assertions, researchers ought to recognize that there are acknowledged difficulties with distinguishing between what constitutes 'genuine' and 'mundane' innovation in different sectors and that has to be accounted for in the research design. 
Internationalization: Recent studies have emphasized that there is an identifiable small business dimension to the choices and processes by which small firms internationalize their operations. Exporting is one of the more basic modes of entry for firms seeking new international markets and on this note, it seems clear enough that most small firms do not export (Storey, 1994; Smallbone et al., 1995; Carter and Jones-Evans, 2000; Alarape, 2007) and many of those that do face distinctive constraints that impede their performance in this area (Ibeh, op. cit. pp.447-449; Prater and Ghosh, 2005). Where it does occur, there seems to be a positive association between increased export orientation and small firm growth (Snell and Lau, 1994; Lu and Beamish, 2001) but the evidence is not clear cut as the connection may have more to do with firm size than it does with firm growth per se.

Technical resources: A firm's possession and use of technical resources can be a valuable tool aiding in particular the implementation of a firm's growth objectives. Specifically, the possession of technical resources can be a moderating factor in overcoming disadvantages associated not only with size but with market experience (Lee et al., 2012). Other things being equal, a small business that adopts greater levels of technological sophistication can be expected to grow more rapidly than a similar firm that does not. In this context however, a key issue will revolve around an acceptable generic definition or benchmark for "technology" since its use as a basis for competitiveness is not uniformly employed by small firms in all sectors.

Planning: The small business sector has long been noted as one in which relatively little formal longrange planning takes place, but there is an indication that the tide may be starting to shift (Kraus et al., 2006). Where it exists, formal, long-range planning in small firms is positively associated with a greater propensity for growth behavior (Masurel and Smith, 2000; Snell and Lau, 1994), but since formal business planning is evidently more present in larger firms, it may be that planning is merely associated with the attendant formality that can arise as a firm transitions towards greater size.

External advice and support: For our purposes, we understand "support" to broadly refer to a firm's need for direct assistance from individuals or agencies outside the organization that are primarily directed at solving specific problems or more generally aiding the development of the firm. Such assistance could take the form of the provision of information, training and consulting services. Delivery agents would include attorneys, accountants, non-profit organizations, as well as various private, state and hybrid agencies. Small businesses are generally thought to be resistant to seeking formal external support (Blackburn et al., 2010), but where it occurs, fast growing firms are thought to seek them out and use them more frequently than slower-growing firms (Storey, 1994). It is, however, an open question whether or not the advice so received is a cause of the growth in question or simply a manifestation of the normal relational orientation of growing firms since mandated contact with support providers tends to increase with the size of the firm (Berry et al., 2006).

Financial resources: Access to and use of financial resources are often critical factors affecting the ability of small businesses to implement growth opportunities. A key issue for most business owners centers on the decision to seek external finance which may open up financial resources but dilute ownership. Small business owners are noted for their unwillingness to share ownership this way (Burns, 2001), with a result that banks become wary of lending to such firms, often demanding safety-net collateral that many small business owners are unable to produce. The resulting financial limitations can operate as a constraint on the firm's growth (Carpenter and Petersen, 2002), for instance by curtailing the rate at which the firm is able to implement innovative plans or adopt progressive technology. As such, small businesses in which the owners are willing to share equity tend to be reported to be more likely to grow than businesses that express a reluctance to share equity.

The need for a consideration of environmental factors: In addition to the preceding three categories examined earlier, it is our view that analytical frameworks for small business growth that do not take sufficient cognizance of the external environment are incomplete because the nature of the relationship that exists between a firm and its external environment is so often a key influence on its performance (Birley and Muzyka, 2000). In the case of small businesses, certain environmental factors have been found to significantly impact firm operations. For instance, small businesses usually cannot create significant market demand through their marketing activities and they tend to operate in local markets in which they are invariably dependent on both their suppliers and dominant customers (Burns, 2001). Attempts have even been 
made to explain the external environment as the central factor explaining small business growth (Kangasharju, 2000). The convergent point is that due to their relatively small scale and market share, smaller firms have comparatively limited opportunities to influence their environment and in that sense tend to face greater external uncertainty and greater dependence on their external environment than their larger counterparts. At the same time however, the flexibility, inventiveness and adaptability for which small businesses are known may enable them to overcome some of the environmental constraints that they face and how successfully individual firms are able to do that may have a significant bearing on their growth performance. In either case, the external environment that a firm operates in is to be considered a key operating factor.

The external environment can be influential on several levels. Global trends and events, along with associated policy responses and the specific socioeconomic climate of towns and regions in which the businesses operate are all external factors that can affect the small firm development process (For the purposes of this study, "policy" is broadly held to refer to the various ways that different levels of government can influence SME development through direct action or wider macro-economic action). The policy dimension is especially important for its ability to determine the political-institutional environment in which businesses operate. Although it would be premature at this point to hypothesize on the type of policy framework that will likely elicit particular responses from small business owners, we do take the view that public policy intends to meet the support needs of business owners for their survival and growth. Yet no one can, with certainty, identify at the point of establishment the firms that would become the so-called high growth 'gazelles' in order for them to receive special support. That possibility, if deemed suitable, does not arise until later when certain tendencies would have been exhibited. At the start-up phase, a key consideration for policy planners seems to be the need to not so much prop up failing companies in order to make them survive, but rather to facilitate a regulatory environment in which encumbrances to business start-up and growth are removed. Furthermore, it is recognized that delivery issues will vary from place to place, but conceptually, the policy environment can be examined for its coherence, in terms of its relationship with other aspects of public policy (e.g., education), as well as it's consistency with the expressed needs of the intended beneficiaries. As such, empirical researchers ought to take a multi- layered approach to conducting environmental analysis. This can take the following forms.

At the national/regional level, environmental analysis typically involves an examination of a set of aggregate factors that are adaptable from the PEST framework or one of its variants (see further, Ireland $e t$ $a l ., 2008$ ) which includes the impact of certain political factors (e.g., taxation and employment regulations), economic factors (e.g., interest rates, unemployment), socio-cultural factors (e.g., demographics, ethnicity) and technological factors (e.g., the adoption and use of technical resources). Secondly, the sectoral level is valuable for inclusion as it defines the conditions in which small firms compete, the technology choices and the nature and extent to which they can innovate (Carter and Jones-Evans, 2000). For this reason, empirical researchers will do well to establish benchmarks that can be used to identify the extent to which the characteristics and behavior of small businesses in particular sectors are similar or different to other firms within the sector. This will provide a basis for analyzing the ways in which small businesses within certain sectors seek growth. Finally, it is worthwhile to examine the relationships between small businesses and their external environment at the local level because it would be of primary importance in helping to identify the factors that aid or constrain the growth of individual firms and can also provide much-needed insights into the extent to which the firm's development is affected by various local infrastructure.

\section{CONCLUSION}

Even though the field has no overarching theory, there is a substantial body of literature on various aspects of small business growth. This study has attempted to review the fundamental approaches to these works as a basis for developing a framework for analyzing the growth process in small firms. Empirical studies indicate that among the entrepreneurs' characteristics influencing small firm growth, the most clearly influential propositions appear to center on the founder's growth motivation, level of education, previous experience with business ownership or management and willingness to team up with other entrepreneurs. Less clear-cut in terms of their association are the impact of the owner's gender or ethnicity. Among the firm's characteristics influencing small firm growth, propositions focusing on the sector in which the firm operates stood out in relation to its ability to influence firm growth. Less clear cut propositions surround the firm's age, location, forms of ownership or employment levels. As far as management 
strategies or practices are concerned, the most clear-cut propositions on factors influencing small firm growth behavior would seem to include the ability to leverage external support and technical resources, as well as the firm's ability to engage in long-range planning activities, develop distinctive marketing strategies and share equity with willing investors. The impact of training-whether of employees or the firm's management-appears to be less clear-cut as a significant factor.

How should we study small firm growth? Citing theirs as well as earlier research, Dobbs and Hamilton (2007) concluded that a unified theory of small firm growth is not only presently unavailable, it is likely to remain outside the reach of scholars. It is no surprise then to find that empirical work in the field is rather fragmented. The variables are complex, contextual and wide-ranging. As noted earlier, it is debatable whether it is even appropriate to seek generalizations from the known diversity of the small business sector. Indeed, a study like the present one can aspire to no more than a point in the direction to which research may proceed and theoretical generalization will need to be cautiously advanced. Conducting a review of the kind attempted in this study illustrates some of the limitations inherent in the process:

First, while it is possible that many of the propositions recognized here will find broad application in SMEs, it is more likely that there will be significant variations dependent on the locations in which they are tested. The studies referenced in this study have been conducted in several parts of Europe and North America as well as in other locations including South Korea, Nigeria and Australia. Methodologically, one may think of this as introducing a helpful diversity to the analyzed material but it could also be thought off as bringing inconsistencies in research outcomes and values that hamper the generalization of the propositions. Secondly, this study has, in certain instances, reviewed some studies that involved the analysis of longitudinal, population data sets, but these are in a minority. Majority of the studies referenced do not fit this bill. The sample size in Snell and Lau (1994) is 21 while Alarape (2007) has a sample size of 62 . Neither set of data was collected over a period of time. This in itself is symptomatic of a wider issue with data access and quality and it is doubtful that this issue will be satisfactorily addressed in the near-term. For instance accurate, reliable and, when necessary, detailed data that will be needed to verifiably explain growth processes in an enterprise are harder to access in smaller/privately-owned enterprises than they would be in larger/publicly-traded ones. Even when these are obtained, a 'snapshot' of some growth dimension may have only captured an episode that is unlikely to yield the kind of insight that will be beneficial to aspiring entrepreneurs, policy planners and even academic researchers who desire to understand the processes by which growth occurs. A longitudinal approach to data collection will go some way to capturing a firm's 'story'-especially the discontinuities that seem to be a part of the growth process in many firms over time. In this regard, the longitudinal data sets of the SBA's Office of Advocacy have helped to generate some persuasive findings, contrary to some of the findings emanating from academia and much of the authority behind the citations of the works of the likes of David Storey, David Smallbone, Brian Headd and certain others in this and other works comes from the longitudinal nature of their empirical analyses. Having said that, the agency datasets tend to be devoid of the entrepreneurs' own narratives that could do much to draw insight from the reams of quantitative data. A qualitative case-based methodology which has a far greater potential to gain insights into the processes and consequences of growth (personal and professional) would be beneficial in these instances. Clearly, academics do not have the survey resources of an organization like the SBA, but more effort can be put into generating respondent panels that can be surveyed over an extended period and qualitative analyses of strands of the agency data sets would also help to generate helpful insights.

Why should we be concerned with small firm growth? As the argument might be presented, most firms are by definition, small: They start small, have a slim-to-fair chance of survival and if they do survive, they invariably remain small. Moreover, most small firm employment generation occurs at the start-up phase. There does however seem to be a demonstrably positive relationship between small firm growth and employment generation. One indicator of the value placed on this relationship in an American context can be seen in the present policy emphasis on employment creation as a primary economic recovery tool. In the aftermath of the global economic downturn of 2008 onwards, the United States lost an estimated 7 million jobs and policy makers have made jobs recovery an integral part of the measurable outcomes for economic recovery. The small business sector is being looked to as a key contributor to this process and for this, it will be necessary for policy planners to have a sound understanding of the enabling and constraining factors on small business development. 
What do we still need to know about small business growth? For the great volume of literature that exists, there remains a need for clear and empirically-based understanding of growth antecedents to inform theory building and policy planning. The relationship between small firm growth and employment generation offers one example. In-depth analyses of US small business data show the (usually media-driven) reports of job losses from a few large firms as driving general employment losses to be more of a myth. Instead, lack of small firm expansion has been demonstrated to be as much a factor in net employment losses during that period as firm employment contraction. In fact, established small firms have been shown to account for as much as $69 \%$ of all net new jobs in the US (Headd, 2010). On a related note, several of the highlighted propositions in this study are not clear, as empirical evidence supporting them is sometimes divided and it is not always clear-cut whether a particular proposition is causal or explanatory. The field would therefore benefit from greater emphasis on predictive, as opposed to the descriptive studies that currently dominate the field. Finally, the field will benefit from a greater understanding of how the external environment-in a variety of social and institutional contexts-influences small firm growth behavior.

\section{REFERENCES}

Alarape, A., 2007. Entrepreneurship programs, operational efficiency and growth of small businesses. J. Enterpris. Commun.: People Places Global Econ., 1: 222-239. DOI: 10.1108/17506200710779530

Assudani, R., 2009. Ethnic entrepreneurship: The distinct role of ties. J. Small Bus. Entrepreneurship, 22: 197-206.

Audretsch, D., 2002. The dynamic role of small firms: Evidence from the US. Small Bus. Econ., 18: 1340. DOI: $10.1023 / \mathrm{A}: 1015105222884$

Bagwell, S., 2008. Transnational family networks and ethnic minority business development. Int. J. Entrepreneurial Behav. Res., 14: 377-394. DOI: 10.1108/13552550810910960

Berry, A.J., R. Sweeting and J. Goto, 2006. The effect of business advisers on the performance of SMEs. J. Small Bus. Enterprise Dev., 13: 33-47. DOI: 10.1108/14626000610645298

Birley, S. and D.F. Muzyka, 2000. Mastering Entrepreneurship. 2nd Edn., Financial Times Prentice Hall, Harlow, ISBN-10: 0273649280, pp: 418.

Blackburn, R., P. Carey and G. Tanewski 2010. Business advice to SMEs: Professional competence, trust and ethics.
Burns, P., 2001. Entrepreneurship and Small Business. Houndmills. 1st Edn., Palgrave, Basingstoke, ISBN-10: 0333914740, pp: 418.

Carpenter, R. and B. Petersen, 2002. Is the growth of small firms constrained by internal finance? Rev. Econ. Stat., 84: 298-309. DOI: 10.1162/003465302317411541

Carter, S. and D. Jones-Evans, 2000. Enterprise and Small Business: Principles, Practice and Policy. 1st Edn., Financial Times, Harlow, ISBN-10: 0201398524, pp: 512.

Chaganti, R., R.G. Cook and W.J. Smeltz, 2002. Effects of styles, strategies and systems on the growth of small businesses. J. Dev. Entrepreneurship, 7: 175-192.

Craig, S.G. and J.E. Kohlhase, 2006. The economic role of small businesses using large data sets: An analysis of the contribution of small firms to urban growth.

Davidsson, P., 1989. Entrepreneurship-and after? A study of growth willingness in small firms. J. Bus. Ventur., 4: 211-226. DOI: 10.1016/08839026(89)90022-0

Dobbs, M. and R. Hamilton, 2007. Small business growth: Recent evidence and new directions. Int. J. Entrepreneurial Behav. Res., 13: 296-322. DOI: 10.1108/13552550710780885

Fadahunsi, A., D. Smallbone and S. Supri, 2000. Networking and ethnic minority enterprise development: Insights from a North London study. J. Small Bus. Enterprise Dev., 7: 228-240. DOI: 10.1108/EUM0000000006842

Fairlie, R.W., 2008. Estimating the contribution of immigrant business owners to the U.S. economy.

Fielden, S., M. Davidson, A. Dawe and P. Makin, 2003. Factors Inhibiting the economic growth of female owned small businesses in North West England. J. Small Bus. Enterprise Dev., 10: 152-166. DOI: 10.1108/14626000310473184

Headd, B. and B. Kirchoff, 2009. The growth, decline and survival of small businesses: An exploratory study of life cycles. J. Small Bus. Manage., 47: 531-550. DOI: 10.1111/j.1540-627X.2009.00282.X

Headd, B. and R. Saade, 2008. Do business definition decisions distort small business research results?

Headd, B., 2010. An Analysis of Small Business and Jobs. 1st Edn., U.S. Small Business Administration, Washington, D.C., pp: 21.

Iacobucci, D. and P. Rosa, 2005. Growth, diversification and business group formation in entrepreneurial firms. Small Bus. Econ., 25: 65-82. DOI: $10.1007 / \mathrm{s} 11187-005-4258-8$

Ireland, R.D., R.E. Hoskisson and M.A. Hitt, 2008. Understanding Business Strategy: Concepts and Cases. 2nd Edn., Cengage Learning, Mason, OH., ISBN-10: 0324578997, pp: 528. 
Kalleberg, A. and K. Leicht, 1991. Gender and organizational performance: Determinants of small business survival and success. Acad. Manage. J., 34: 136-161. DOI: $10.2307 / 256305$

Kangasharju, A., 2000. Growth of the smallest: Determinants of small firm growth during strong macroeconomic fluctuations. Int. Small Bus. J., 19: 28-43. DOI: $10.1177 / 0266242600191002$

Kobe, K., 2007. The Small Business Share of GDP, 1998-2004. Small business administration office of advocacy.

Kraus, S., R. Harms, E.J. Schwarz, 2006. Strategic planning in smaller enterprises-new empirical findings. Manage. Res. News, 29: 334-344. DOI: 10.1108/01409170610683851

Lee, H., D. Kelley, J. Lee and S. Lee, 2012. SME survival: The impact of internalization, technology resources and alliances. J. Small Bus. Manage., 50: 1-19. DOI: 10.1111/j.1540-627X.2011.00341.x

Lowrey, Y., 2010. Race/ethnicity and establishment dynamics, 2002-2006.

Lu, J. and P. Beamish, 2001. The internationalization and performance of SMEs. Strategic Manage. J., 22: 565-586. DOI: 10.1002/smj.184.abs

Masurel, E. and H.P. Smith, 2000. Planning behavior of small firms in central vietnam. J. Small Bus. Manage., 38: 95-102.

Morris, M., N. Miyasaki, C. Watters and S. Coombes, 2006. The dilemma of growth: Understanding the venture size choices of women entrepreneurs. J. Small Bus. Manage., 44: 221-244. DOI: 10.1111/j.1540-627X.2006.00165.x

Perrault, W.D., J. Cannon and E.J. McCarthy, 2010. Basic Marketing. 18th Edn., McGraw-Hill Companies, New York, ISBN-10: 0073529958, pp: 832.

Prater, E. and S. Ghosh, 2005. Current operational practices of U.S. small and medium-sized enterprises in Europe. J. Small Bus. Manage. 43: 155-169. DOI: 10.1111/j.1540-627x.2005.00131.x
Ram, M., D. Deakins and D. Smallbone, 1997. Small Firms: Enterprising Futures. 1st Edn., Paul Chapman, London, ISBN-10: 1853963755, pp: 208.

Robinson, S. and J. Finley, 2007. Rural women's selfemployment: A look at Pennsylvania. Acad. Entrepreneurship J., 13: 21-30.

Savery, L.K. and J.A. Luks, 2004. Does training influence outcomes of organisations? Some Australian Evidence. J. Manage. Dev., 23: 119123. DOI: $10.1108 / 02621710410517210$

Scott, D.M., R. Curci and R. Mackoy, 2012. Hispanic business enterprise success: Ethnic resources, market orientation or market exchange embeddedness? J. Int. Bus. Cultural Stud., 6: 1-19.

Smallbone, D., R. Leigh and D. North, 1995. The characteristics and strategies of high growth SMEs. Int. J. Entrepreneurial Behav. Res., 1: 45-62. DOI: $10.1108 / 13552559510100657$

Snell, R. and A. Lau, 1994. Exploring local competencies for expanding small businesses. J. Manage. Dev., 13: 4-15. DOI: $10.1108 / 02621719410057032$

Storey, D.J., 1994. Understanding the Small Business Sector. 1st Edn., Routledge, London, ISBN-10: 0415100380, pp: 355.

Storey, D.J., 2004. Explaining the links among small firms between management training and firm performance: A Comparison between the UK and other OECD countries. Int. J. Resource Manage., 15: 112-130. DOI: 10.1080/0958519032000157375

USSBA, 2004. The Small Business Economy: A Report to the President. 1st Edn., Small Business Administration, Washington DC., pp: 150.

USSBA, 2008. The Small Business Economy: A Report to the President. 1st Edn., Small Business Administration, Washington DC., pp:373. 